\title{
Editorial
}

\section{Fraud and other misconduct in biomedical research}

\author{
R. Illingworth
}

Research makes such a significant contribution to medical practice and to the health of the nation that it would be complacent to assume its continued good health. In 1988 Stephen Lock, then editor of the British Medical Journal, asked whether misconduct in medical research existed in Britain and undertook a personal survey ${ }^{14}$. He concluded that such misconduct did indeed exist, and that urgent action was required to counter it and maintain public confidence ${ }^{14}$. Since that time little has been done until recently, but a small group of British editors has continued to write expressing concern over the lack of processes to counter the problem ${ }^{2,5,6}$. A small number of high profile cases involving British researchers in prestigious medical institutions has come to light ${ }^{4,8,15}$, but these may well be only the visible part of a much greater problem. Some cases may go undetected, and others are probably dealt with without publicity within the Institutions in which they occur. These cases are gross and deliberate frauds involving fabrication or falsification of data, or plagiarism of other researchers work. Much more common is research misconduct comprising a whole range of activities which do not conform to good research practice, and cannot be considered acceptable.

There are many definitions of such misconduct but they include omission of patients not conforming to the rest of the data, inventing additional patients, and changing some of the data $^{20}$. More common are multiple publications of the same material, breaking a single piece of work down into multiple publications (salami slicing), gift authorship, conflicts of interest influencing publication and bias by reviewers or even editors ${ }^{7}$. Such misconduct as multiple publications may sometimes be detected by reviewers, but can easily be identified in retrospect by the use of MEDLINE. A study of one year's publications in three general surgical journals showed that nearly $14 \%$ were duplicate or salami sliced publications ${ }^{21}$. Similar results have been found in an orthopaedic journal and in $\mathrm{ENT}^{3,10}$. Checking of references sometimes shows that arguments are supported by references to other publications which are in fact not supportive.

Recibido: 29-07-05
So why does this happen? Clearly in generously funded research, usually supported by pharmaceutical firms, financial gain can provide a strong motivation, particularly for those working independently. In centres of clinical research the motives may well be more complicated. The pressures to publish to achieve promotion, or even to retain employment may be intense, but probably more significant may be the ambition to be famous. The ranking of academic institutions by the number of publications and size of research grants could well be a factor in provoking a climate of competition, which could distort researchers' perception of what is acceptable. Certainly the motivation is there, and also the means and opportunity. Detection may well be very difficult and once successful fraud has been performed the temptation to repeat it may well be very strong ${ }^{16}$. The consequences of detecting such activity, particularly if this becomes public knowledge, can be very damaging for research institutions. It is likely therefore that such fraudulent misconduct does occur, and that organisations will wish to avoid even internal publicity.

These concerns have led to initiatives which have produced the Uniform Requirements for Manuscripts Submitted to Biomedical Journals, commonly known as the Vancouver guidelines ${ }^{11}$, and more recently the forming of COPE, the Committee on Publication Ethics ${ }^{22}$, which has now a large membership of British biomedical journals. COPE holds meetings, and publishes an annual report in which members or invited speakers discuss current issues of publication ethics ${ }^{26}$. COPE will also review and advise on anonymised cases of concern. The results of discussion and outcome in such cases are published by COPE in its annual report ${ }^{26}$.

Initially when the editors raised their concerns they felt that some national organisation should be established to monitor and regulate standards of behaviour by medical researchers ${ }^{6,23}$. Such bodies have been established in a number of other countries, notably the United States and some Scandinavian countries. However there was a view that such a body was not necessary in Britain because research fraud misconduct was rare, and when it occurred it could be most effectively dealt with by the organisations 
in which it was discovered ${ }^{13}$. Some way towards providing a national framework has been produced by the establishment of Research Governance, which provides a register of research activity in each institution and links in with mandatory submission to Medical Research Ethics Committees $^{17}$. There is also a developing protocol for the investigation of suspected research fraud with adjudication independently of the process of investigation, and referral to the General Medical Council if appropriate ${ }^{25}$.

However, all this deals largely with maintenance of a register of research activity, and addressing the problem once research fraud or misconduct is suspected. The issue of prevention, which must be in principal more desirable, remains as yet largely undeveloped, despite the opportunities in undergraduate medical training, the supervision of research, and the processes for employment and publication. There is no particular reason why members of the medical profession or scientific community should be any more honest than the general public. The results of studies to investigate the honesty of medical students and researchers are not encouraging. An American study of biomedical trainees showed that $23 \%$ had received no if training in research ethics, 36\% had observed some kind of scientific misconduct, and that $15 \%$ were prepared to manipulate research data to obtain a grant or achieve publication ${ }^{12}$. Another study looked at the percentage of medical students and staff who were aware of or had participated in cheating. The study showed that the estimates of the medical students of the percentage of their fellows who cheated grew progressively during the four years of the study, and that their teachers largely agreed with these estimates ${ }^{1}$. Confidence that this was a North American phenomenon must have been dispelled by the report that a medical student in a London medical school who cheated in the final examination was allowed to pass $^{24}$.

There needs to be a change in culture. No longer can it be possible to believe that such fraud and misconduct is rare, and that when detected it can be handled informally within the establishment. The medical undergraduate curriculum needs to include teaching not only on the ethics of clinical practice but also the ethics of medical research. The institutions in which such research is carried out need to reinforce such earlier teaching with induction courses, and to write into contracts of employment a requirement to report any suspicion of such misconduct, to cooperate in any investigation, and to retain the original data sheets ${ }^{25}$. It should be made clear that the data are not the property of the individual researcher but rather of the institution in which the research has taken place, or the outside body which has funded it. There should be well publicised policies to protect whistleblowers, going beyond the Public Interest Disclosure Act 1998, which gives whistleblowers the right to claim for dismissal, provided the correct pro- cedures have been followed, but does not otherwise protect employment ${ }^{19}$. The Medical Research Council and the Royal College of Physicians have produced papers detailing policies and procedures for the investigations of allegations of biomedical fraud and misconduct ${ }^{9,18}$ and similar procedures need to be established in every organisation in which research takes place. Research supervisors may need to be more actively involved in not only the supervision but also the conduct of research, and to be prepared to look at the raw experimental data. The biomedical journals have also a role to play. Clearly their role is not to investigate cases of suspected fraud or misconduct; that is a role that most appropriately falls to employers or regulators such as the GMC. What journals can do is to update their Instructions to authors to address such issues as conflicts of interest, not only for those that submit for publication, but also for reviewers and editors. Reviewers should be asked to consider, not only the quality of the work submitted and its originality, but also whether it could have been published elsewhere, and whether there is any other suspicion of fraud or misconduct. The question of the authorship needs to be addressed. It is no longer acceptable that the head of a department should automatically be one of the authors of a paper, even if he or she has written the successful grant application $^{14}$. Each author should be required to identify exactly what contribution has been made since there are now well established criteria for authorship ${ }^{11}$.

The medical and scientific communities still enjoy a high reputation among the general public. To maintain this the biomedical research community should ensure that there are procedures In place to promote a culture of intellectual honesty, and effective mechanisms to address failures when these occur.

\section{Acknowledgements}

I am happy to acknowledge invaluable advice from Dr Richard Smith Editor of the BMJ, Dr Rodney Gale, Director of Research Support and Professor Christopher Kennard, Clinical Director, Neurosciences at Hammersmith Hospitals NHS Trust. For those wishing to learn more about this important subject I recommend Fraud and Misconduct in Biomedical Research edited by Lock, Wells and Farthing, ISPN 0-7279-1509-8, 2001 published by BMJ books.

This editorial has been published with permission of the author and of the Editor of the "British Journal of Neurosurgery".

\section{References}

1. Anderson, R.E., Obenshain, S.S.: Cheating by students: 
findings, reflections and remedies. Acad Med 1994; 69: 323332.

2. Anonymous. Dealing with deception. Lancet 1996; 347 : 843.

3. Bailey, B.J.: Duplicate publications in the field of otolaryngology-head and neck surgery. Otolaryngol Head Neck Surg 2002; 126: 211-216.

4. Dyer, C.: Consultant struck off over research fraud. BMJ 1997; 315: 205.

5. Farthing, M.: An editor's response to fraudsters. BMJ 1998; 316: 1729-1731.

6. Farthing, M., Horton, R., Smith, R.: Research misconduct: Britain's failure to act. BMJ 2000; 321: 1485-1486.

7. Farthing, M.: Research misconduct: an editor's view: In Lock, S., Wells, F., Farthing, M., eds, Fraud and misconduct in biomedical research. $3^{\text {rd }}$ edition. London: BMJ Books 2001; 244-256.

8. Ferriman, A.: Consultant suspended for research fraud. BMJ 2000: 321: 1429.

9. Fraud and Misconduct in Medical Research. Causes, Investigation and prevention. The Royal College of Physicians of London; 1991.

10. Gwilym, S.E., Swan, M,C., Giele, H.: One in 13 "original" articles in the Journal of Bone and Joint Surgery are duplicate or fragmented publications. JBJS 2004; 86 B: 937-938.

11. International Committee of Medical Journal Editors. Uniform requirements for manuscripts submitted to biomedical journals. Ann Int Med 1997;126: 36-47.

12. Kalichman, M.W., Friedman, P.J.: A pilot study of biomedical trainees' perceptions concerning research ethics. Acad Med 1992; 67: 769-775.

13. Lachmann, P.: The Research Integrity Initiative: progress report. In White C, ed., The COPE Report 2002.
2005; 16: A-B

Committee on Publication Ethics. London: BMJ Books 2002: 8-12.

14. Lock, S.: Misconduct in medical research: does it exist in Britain? BMJ 1988; 297: 1531-1535.

15. Lock, S.: Lessons from the Pearce affair: handling scientific fraud. BMJ 1995; 310; 1547-1548.

16. Lock, S.: Research misconduct 1974-1990: an imperfect history. In: Lock, S., Wells, F., Farthing, M., eds, Fraud and misconduct in biomedical research. $3^{\text {rd }}$ edition. London: BMJ Books 2001; 51-63.

17. Mayor, S.: New governance framework for NHS research alms to stop fraud. BMJ 2000; 321:725.

18. MRC Policy and Procedure for Inquiring Into Allegations of Scientific Misconduct. London: MRC December 1997.

19. Public Interest Disclosure Act 1998. London: Stationery Office.

20. Rennie, D., Gunsalus, C.K.: Regulations on scientific misconduct: lessons from the US experience. In Lock, S., Wells, F., Farthing, M., eds, Fraud and misconduct in biomedical research. $3^{\text {rd }}$ edition. London: BMJ Books 2001; 13-31.

21. Schein, M., Paludugu, R.: Redundant surgical publications: tip of the iceberg? Surgery 2001; 129: 655-661.

22. Smith, R.: Misconduct in research: editors respond. BMJ 1997; 315: 201-202.

23. Smith, R.: The need for a national body for research misconduct. BMJ 1998; 316: 1686-1687.

24. Smith, R.: Cheating at medical school. Justice must be done and seen to be done. BMJ 2000; 321: 298.

25. Tomlinson, S.. Catto, G.R.D.: Fraud and misconduct in biomedical research: how should we respond? Proc. RCP Edin 2000; 30 supp1 7: 18-21.

26. White, C., ed.. The COPE Report 2002. Committee on Publication Ethics. London: BMJ Books 2002.

\section{Comentario al Editorial}

\section{Poza}

Hace unos meses, el Dr. Robin Illingworth, y yo cambiamos impresiones sobre la conveniencia de publicar un editorial sobre "Etica en la investigación". El Dr. Illingworth me precedió en la presidencia del Comité de Etica de la EANS. En uno de los números recientes de "Neurocirugía", (octubre, 2004) escribí una revisión del libro titulado "Fraud and misconduct in biomedical research". Después leí este editorial de Illingworth en el "British Journal of Neurosurgery" y me pareció oportuno reproducirlo en nuestra revista, con la debida autorización del editor del BJN, en lugar de hacer un artículo conjunto, como proponía su autor.

Es muy probable que la situación española no sea parecida a la inglesa o a la de otros países anglosajones. Al menos no se han detectado casos escandalosos, con gran repercusión mediática. Sin embargo, cabe adoptar alguna medida preventiva sobre ciertos puntos de "conductas inapropiadas", puntos que deben ser tenidos en cuenta por las personas que revisan los trabajos, cuando recomienden sean aceptados para su publicación. La fragmentación de un trabajo en varios artículos (efecto salami) y su publicación en distintas revistas, la reiteración de artículos con 
el mismo tema, al cual se añaden pequeños e irrelevantes datos, el maquillaje de números con el fin de obtener resultados con significación estadística, la falta de rigor en las citas de autores en la bibliografía, el excesivo número de autores o la presión para que el jefe figure en todas las publicaciones, son algunos puntos que han de estar presentes al dar lúz verde. Sería deseable que figurara la aportación de cada autor.

La conciencia laxa en el rigor científico, (tal como se ha observado en una encuesta realizada a estudiantes y jóvenes investigadores, -capaces de engañar con el fin de que su trabajo fuera admitido en una revista importante-), debe ser reeducada. Tal vez haya que cambiar los baremos y dejar de valorar el "peso del papel publicado" por el significado de
2005; 16: A-B

su contribución.

Si esta falta de ética fuera frecuente en España, en cualquier campo de la medicina, habría que cambiar nuestra forma de entender la cultura científica, tal como dice Illingworth. Es preferible publicar un trabajo con resultados contrarios a las hipótesis que falsificar los datos, para impresionar a los revisores del Consejo Editorial y facilitar la aceptación del mismo. Se tiene la impresión de que los resultados "negativos" tienen poco o ningún valor. Sin embargo, son los que han permitido derribar dogmas médicos que habían resistido el paso de los años. Los números que reflejan la morbimortalidad deben ser reales, sin afán de deslumbramiento. La comunidad científica y la sociedad en general no se merecen el engaño. 